Article

\title{
Glacier Changes in the Qilian Mountains, Northwest China, between the 1960s and 2015
}

\author{
Jing $\mathrm{He}^{1,2}{ }^{-}$, Ninglian Wang ${ }^{1,2,3, *}$, An'an Chen ${ }^{1,2}\left(\right.$, Xuewen Yang ${ }^{1,2}$ and Ting Hua ${ }^{1,2}$ \\ 1 Shaanxi Key Laboratory of Earth Surface System and Environmental Carrying Capacity, College of Urban \\ and Environmental Sciences, Northwest University, Xi'an 710127, China; hejing1995@126.com (J.H.); \\ chenanan1126@163.com (A.C.); yxw_0117@163.com (X.Y.); hactgexin@lzb.ac.cn (T.H.) \\ 2 Institute of Earth Surface System and Hazards, College of Urban and Environmental Sciences, \\ Northwest University, Xi'an 710127, China \\ 3 CAS Center for Excellence in Tibetan Plateau Earth Sciences, Beijing 100101, China \\ * Correspondence: nlwang@nwu.edu.cn
}

Received: 24 January 2019; Accepted: 22 March 2019; Published: 26 March 2019

\begin{abstract}
Glaciers in the Qilian Mountains are important sources of fresh-water for sustainable development in the Hexi Corridor in the arid northwest China. Over the last few decades, glaciers have generally shrunk across the globe due to climate warming. In order to understand the current state of glaciers in the Qilian Mountains, we compiled a new inventory of glaciers in the region using Landsat Operational Land Imager (OLI) images acquired in 2015, and identified 2748 glaciers that covered an area of $1539.30 \pm 49.50 \mathrm{~km}^{2}$ with an ice volume of $81.69 \pm 7.40 \mathrm{~km}^{3}$, among which the Shule River basin occupied the largest portion of glaciers $(24.8 \%$ in number, $32.3 \%$ in area, and $35.6 \%$ in ice volume). In comparison to previous inventories, glacier area was found to shrink by $396.89 \mathrm{~km}^{2}$ $(20.5 \%)$ in total, and 109 glaciers with an area of $8.94 \mathrm{~km}^{2}$ disappeared over the period from the $1960 \mathrm{~s}$ to 2015 . This situation was primarily caused by the increase in air temperature, and also related with the size of glacier and some local topographic parameters. In addition, the change of glaciers in the Qilian Mountains showed a distinct spatial pattern, i.e., their shrinking rate was large in the east and small in the west.
\end{abstract}

Keywords: glacier changes; the Qilian Mountains; climate factors

\section{Introduction}

Glaciers are considered as key indicators of climate change [1], potentially contributing to water resources and global sea level rise [2]. Alpine glaciers are vital component of global cryosphere [3]. Global warming has significant impacts on glaciers worldwide [4], and the majority of mountain glaciers have suffered from rapid retreat in recent decades [5]. The shrinkage rate of glacier area generally increased from the continental interior to the Himalayas and peaked in the southeastern Tibetan Plateau (TP), with an area reduction rate of $-0.57 \% \mathrm{a}^{-1}$ from 1970 s to 2000s [6]. Glaciers and glacial meltwater are the most important fresh-water resources and play a critical role in maintaining ecological balance and social and economic sustainable development in the Qilian Mountains, located in the northeastern edge of the TP [7].

Glaciers in the Qilian Mountains are of great significance to the runoff recharge in the Hexi Corridor, populated by over 4.5 million people [8]. Where a number of efforts has been made to monitor glacier changes here. Tian et al. (2014) [8] found that the glacier area in the Qilian Mountains has shrunk by 30\% $\pm 8 \%$ from 1956 to 2010 and the shrinkage accelerated remarkably in the past two decades. Sun et al. (2018) [9] showed in the past half-century (1960s to 2010), the area and volume of glaciers in the Qilian Mountains have decreased by $420.81 \mathrm{~km}^{2}(-20.88 \%)$ and $21.63 \mathrm{~km}^{3}(-20.26 \%)$, 
respectively. Wang et al. (2013) [10] reported an annual glacier mass loss of $(534.2 \pm 399.5) \times 10^{6} \mathrm{~m}^{3}$ w.e. (water equivalent) in the Qilian Mountains based on the Ice, Cloud, and Land Elevation Satellite (ICESat) altimetry data for 2003-2009, despite of the relatively higher uncertainty for small scale glaciers and sparse distribution of ICESat ground tracks, However, the results of Jacob et al. (2012) [11] indicated a positive glacier mass balance of $7 \pm 7 \mathrm{Gt}_{\text {year }}{ }^{-1}$ in Tibet and Qilian Shan from 2003 to 2010. These above results show a good consistency, except the last, which is due to the much larger research area, Tibet.

Glacier area is an important parameter for mass balance change and model simulation research. Recent studies regarding the glacier area and volume loss document in the Qilian Mountains have focused primarily on its sub-regions [12,13] and may have some differences even in the same region probably due to the different data resources, study period and interpretation methods based on remote sensing [14]. Therefore, the aims of this study are to (1) retrieve the outline of glaciers in the Qilian Mountains by 2015 using remote-sensing data, thereby providing basic data for regional mass balance estimation, (2) provide information on the contemporary distribution of glaciers based on the First Chinese Glacier Inventory (FCGI), the Second Chinese Glacier Inventory (SCGI) and the accomplished inventory of 2015, and (3) analyze glacier changes and possible climatic drives for glaciers in the mountain range.

\section{Study Area}

The Qilian Mountains are located in the northeastern margin of the Tibetan Plateau, extending from Wushaoling westward to Dangjin Shankou, connected to the Altun Mountains [15], and are composed of a series of northwest to southeast mountains and valleys [16]. The study area covers $\sim 220,000 \mathrm{~km}^{2}$ and the elevation gradually increases from the northeast to southwest, spanning an elevation range from 4000 to 5200 m, with Mount Tuanjie as the highest peak located in the Shule Nanshan (5826.8 m) [16].

The region lies in a transitional zone between the arid northwestern China and the alpine Tibetan Plateau [8], and thus is controlled by westerly winds in the west where precipitation is sparse and affected by the Asian summer monsoons in the east [9] where precipitation is relatively abundant. Precipitation is mainly concentrated in the summer, and the annual precipitation and warm season precipitation all show trends of decreasing from east to west. The drainage system in the mountains is oriented NW-SE. Figure 1 shows the location map of the study site.

According to our glacier inventory of 2015 for the Qilian Mountains, there were 2748 glaciers with an area of $1539.30 \mathrm{~km}^{2}$, ranking 9th out of 14 mountains in western China with glaciers [17]. There are also two types of glaciers in the mountains: subcontinental glaciers in the central and eastern region, and extreme continental (polar) glaciers in the west [8].

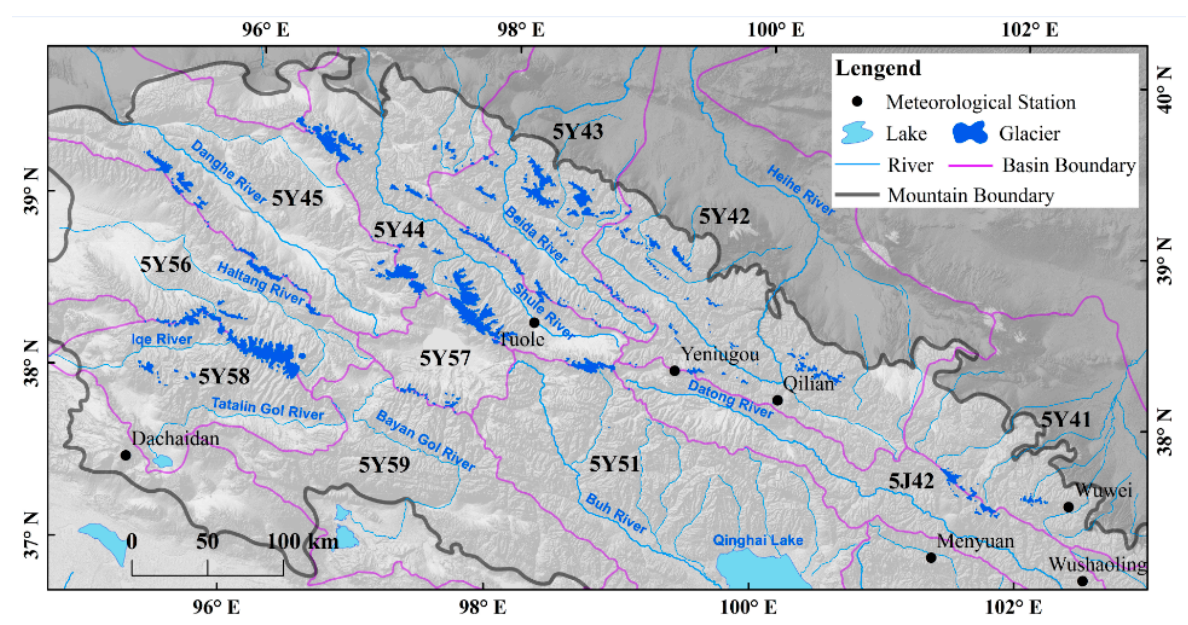

Figure 1. The glaciers distribution in the Qilian Mountains. 


\section{Data and Methods}

\subsection{Data}

\subsubsection{Landsat Imagery}

We used 18 Landsat 8 Operational Land Imager (OLI) images with a $30 \mathrm{~m}$ spatial resolution from 2013 to 2016. The Landsat scenes with minimal cloud and snow cover were selected from paths 132-137 and rows 033-034 in the Worldwide Reference System 2. The Landsat data was available from USGS Earth Explorer (https:/ / glovis.usgs.gov/), and the series of Landsat scenes were preprocessed with Standard Terrain Correction (Level 1T) by the United States Geological Survey (USGS). The months of these imagery were mainly concentrated in summertime.

Before glacier delineation, the image sharpening operation was processed in all images to a $15 \mathrm{~m}$ resolution, which would effectively reduce errors caused by pixel resolution.

\subsubsection{First Chinese Glacier Inventory (FCGI) and Second Chinese Glacier Inventory (SCGI)}

The compilation of the FCGI dataset was based on topographic maps and aerial photographs acquired from the 1950s to the 1980s by Chinese glaciologists [16]. In addition, most of the aerial photographs used in the interpretation of the glacier in Qilian Mountains were taken in 1956, and the rest in 1963. Therefore, 1960s was selected as the median date for the mountains. The SCGI dataset released in December 2014 was compiled using geographic information system (GIS) and remote-sensing techniques, after validations with in situ field investigations and detailed monitor of selected glacier changes, covering $86 \%$ of the glacierized area of China compared to the digitized FCGI. In total, 218 Landsat scenes were used in SCGI, with 92\% of them being taken during 2006-10 [18].

\subsubsection{Digital Elevation Models}

We employed the Shuttle Radar Topography Mission (SRTM) V4.1 to acquire the elevation attributes of glaciers as it shows less error throughout the central Tibetan Plateau than the Advanced Spaceborne Thermal Emission and Reflection Radiometer Global Digital Elevation Model 2 (ASTER GDEM 2) when compared with ICESat GLA 14 [19]. The SRTM was provided by the Consultative Group on International Agricultural Research (CGIAR, http:/ / srtm.csi.cgiar.org/).

\subsubsection{Climate Data}

Monthly temperature and precipitation data for the period 1960-2015 at seven meteorological stations (Table 1) around glaciers, were obtained from the China Meteorological Data Service Centre (http:/ / data.cma.cn/). Moreover, the CRU (Climatic Research Unit) TS v.4.01 land precipitation and air temperature datasets were used in this study to analyse the spatial distribution and change pattern of glaciers, which are based on monthly observational data from 1901 to 2015 with a high resolution $(0.5 \times 0.5$ degree $)$.

Table 1. The location of seven meteorological stations in the Qilian Mountains.

\begin{tabular}{ccccc}
\hline Station Number & Name & Latitude & Longitude & Elevation \\
\hline 52633 & Tuole & 38.48 & 98.25 & 3820 \\
52645 & Yeniugou & 38.25 & 99.35 & 4429 \\
52657 & Qilian & 38.11 & 100.15 & 3597 \\
52679 & Wuwei & 37.55 & 102.4 & 3272 \\
52713 & Dachaidan & 37.51 & 95.22 & 3425 \\
52765 & Menyuan & 37.23 & 101.37 & 3502 \\
52787 & Wushaoling & 37.12 & 102.52 & 3339 \\
\hline
\end{tabular}




\subsection{Methods}

\subsubsection{Glacier Outline Delineation}

We applied a semi-automated method using the Red/Shortwave Infrared (SWIR) band ratio with an appropriate threshold to extract glacier outlines. This method is most applicable and effective for glacier classification according to the Global Land Ice Measurement Form Space (GLIMS) protocol $[14,20]$. However, the automated mapping of glaciers might be inaccurate or misclassified when the quality of image is affected by the presence of clouds, seasonal snow, glacier lakes, mountain shadow regions and debris-covered parts, which makes it essential to improve the automatic delineation results manually [20].

We used different band combinations to solve the main problems of the automated method. True color composite images were used for the general situation in glacier delineation, while the false color images were utilized to distinguish ice and snow from cloud owing to the weak absorption of clouds in the SWIR. In addition, the high-resolution Google Earth ${ }^{\mathrm{TM}}$ imagery was used to verify glaciers with large shadow or termini ending in lakes and some regions where image quality was unsatisfactory.

The accurate discrimination of a glacier from cloud and snow depends more on operational experience rather than a clear standard, and therefore one operator made all manual improvements so as to ensure consistency and comparability across the entire region [21]. The accuracy of manually digitized glacier boundary is within half pixel. Attributes of glaciers such as aspect, elevation, etc., were calculated using methods that Paul suggested [14].

\subsubsection{Calculation of Glacier Area Variation}

Changes in glacier area were expressed as the difference between each of three glacier inventories. The normalized percentage (AP, $\%)$ and rates of glacier change $\left(\mathrm{AR}, \% \mathrm{a}^{-1}\right)$ were used to measure the area variation to avoid the interference of differing size of glaciers and time interval between three inventories, which are calculated as follows [22]:

$$
\begin{gathered}
\mathrm{AP}=100\left(\mathrm{~S}_{1}-\mathrm{S}_{0}\right) / \mathrm{S}_{0} \\
\mathrm{AR}=\mathrm{AP} / \Delta \mathrm{t}=\mathrm{AP} /\left(\mathrm{t}_{1}-\mathrm{t}_{0}\right)
\end{gathered}
$$

where $S\left(\mathrm{~km}^{2}\right)$ represents glacier area and $\mathrm{t}$ represents year, subscript 0 and 1 denotes the earlier and later time of any two inventories, respectively. The comparable AR is a 'simple-interest' calculation for being divided by the initial area $\mathrm{S}_{0}[23]$.

\subsubsection{Uncertainty Assessment}

The sources of glacier delineation uncertainties can be divided into three types [24,25]: technical uncertainties, interpretation uncertainties, and methodological uncertainties. Technical uncertainties can be ignored for the images we applied are orthorectified. Interpretation uncertainties are mostly decided for the purposes of inventory compilation and are difficult to evaluate. Methodological uncertainties depend on the resolution of the Landsat images and the skills of the interpretation operator [26], which can be assessed in this study.

The area error assessed by glacier buffers [4,27] is feasible because it depends strongly on the glacier size, and therefore, the uncertainty of the outline position $\left(\mathrm{E}_{\mathrm{A}}\right)$ is expressed as half of an image pixel [28] multiplied with the length of glacier boundary. We also represent the area uncertainties as percentages of the total glacier area. In addition, the errors from the interior ice divides are also ignored at watershed or larger scales [18]. The uncertainty of glacier area changes $\left(\mathrm{E}_{\mathrm{AC}}\right)$ is calculated by adding the area uncertainties in quadrature [22,29]. $\mathrm{E}_{\mathrm{A}}$ and $\mathrm{E}_{\mathrm{AC}}$ can be expressed as follows:

$$
\mathrm{E}_{\mathrm{A}}=\mathrm{N} \cdot \lambda^{2} / 2
$$




$$
\mathrm{E}_{\mathrm{AC}}=\sqrt{\left(\mathrm{E}_{\mathrm{A}_{0}}\right)^{2}+\left(\mathrm{E}_{\mathrm{A}_{1}}\right)^{2}}
$$

where $\mathrm{E}_{\mathrm{A}}$ represents area uncertainties, $\mathrm{N}$ is the number of pixels along the boundary of glaciers, and $\lambda$ is the spatial resolution ( $15 \mathrm{~m}$ for processed Landsat 8 imagery). The uncertainty of our inventory due to image spatial resolution was $\pm 49.50 \mathrm{~km}^{2}( \pm 3.21 \%)$.

\section{Results}

\subsection{The Glacier Distribution in 2015}

In total, there were 2748 glaciers with an area of $1539.30 \pm 49.50 \mathrm{~km}^{2}$ in 2015 , unevenly distributed within different basins. Generally, only a small number of glaciers accounts for most of the total area, while the rest of the smaller glaciers that are larger in number occupy a small proportion $[30,31]$, which still holds in the Qilian Mountains. As shown in Figure 2, glaciers with areas ranging from 2 to $5 \mathrm{~km}^{2}$ covered a larger area $(23.8 \%)$ of the total glacier area in the Qilian Mountains (Figure 2a), occupying merely $4.4 \%$ of the total number, whereas the higher number of glaciers can be found in the size class $<0.1 \mathrm{~km}^{2}$ and $0.1-0.5 \mathrm{~km}^{2}$ (Figure $2 \mathrm{~b}$ ), accounting for $37.4 \%$ and $38.0 \%$ of the whole number, but $3.1 \%$ and $16.7 \%$ of entire area, respectively. The biggest glacier named Laohugou No.12 Glacier covered an area of $20.22 \mathrm{~km}^{2}$, located in the Shule River basin.

There are some different distribution of the glaciers within different area classes in drainage basin scale and the overall regional trends. The statistics of glaciers in different watersheds are listed in Table 2. The Shule River (5Y44) basin had the largest number (24.8\%) and area (32.3\%) of the glaciers, while the number of glaciers was the second largest (21.3\%) in the Beida River (5Y43) basin, but its area occupied $13.5 \%$, which was only less than half that of Shule River. Almost all basins had its majority number $(>70 \%)$ of glaciers with an area of less than $0.5 \mathrm{~km}^{2}$ (Figure $2 \mathrm{~d}$ ). The basin with least glaciers resources was the Bayan Gol River, with only 10 glaciers covering an area of $2.11 \mathrm{~km}^{2}$. The Bayan Gol River basin (5Y59) and Heihe River basin (5Y42) had the largest area proportions ( $>80 \%$ ) of glaciers smaller than $1 \mathrm{~km}^{2}$ (Figure 2c), indicating that more glaciers in these basins are small.

Table 2. Glacier distributions in different drainage basins from three inventories.

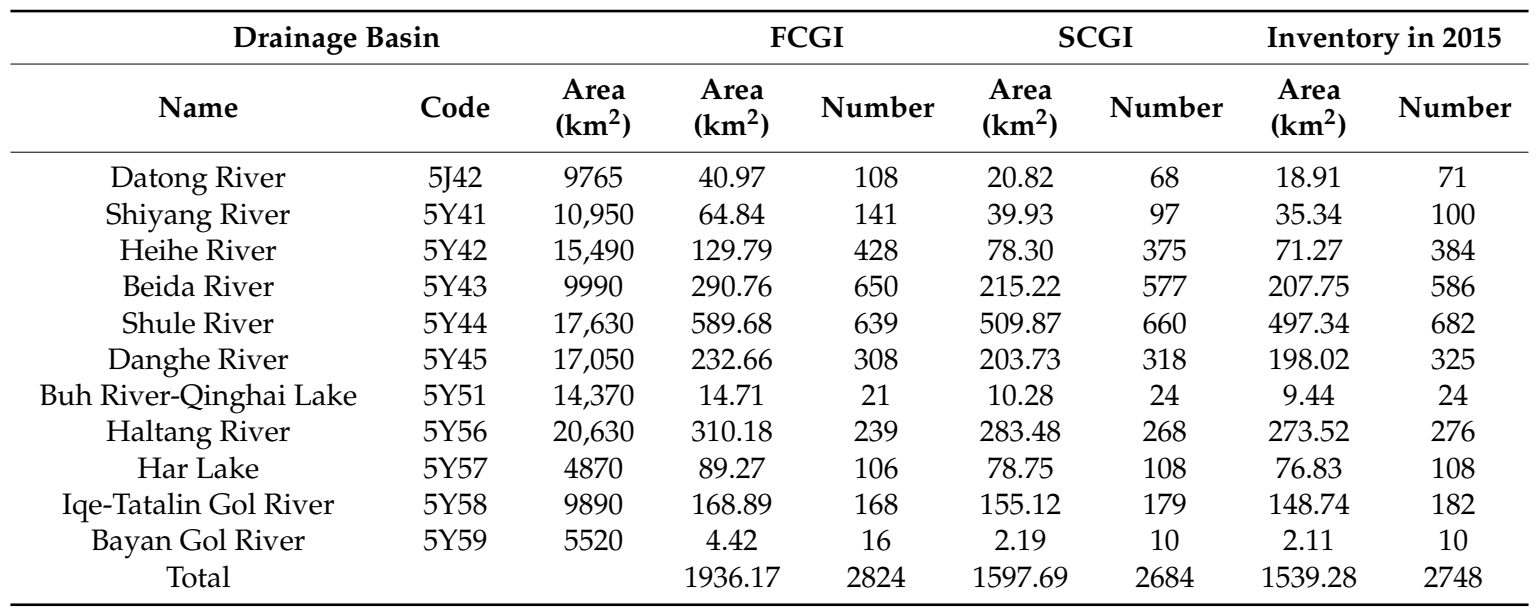

Notes: FGGI: First Chinese Glacier Inventory. SCGI: Second Chinese Glacier Inventory.

The statistical analysis with a $200 \mathrm{~m}$ elevation increment shows that the hypsography of the glacier area in the Qilian Mountains presented a spatial difference and quasi-normal distribution (Figure 3a). The elevation of glaciers ranged from 4017 to $5764 \mathrm{~m}$ and increased from northeast to southwest along the parallel mountains and valleys with NE trend. Glaciers located between 4700-5300 m accounted for $76.3 \%$ of the total area of glaciers, while the least proportion of glaciers area (only about $0.8 \%$ ) was found in those over $5500 \mathrm{~m}$. The spatial pattern of glacier distribution by altitude shows that most 
glaciers in the western Qilian Mountains are located at an elevation of $>4700 \mathrm{~m}$ while glaciers in the east developed below $4500 \mathrm{~m}$.
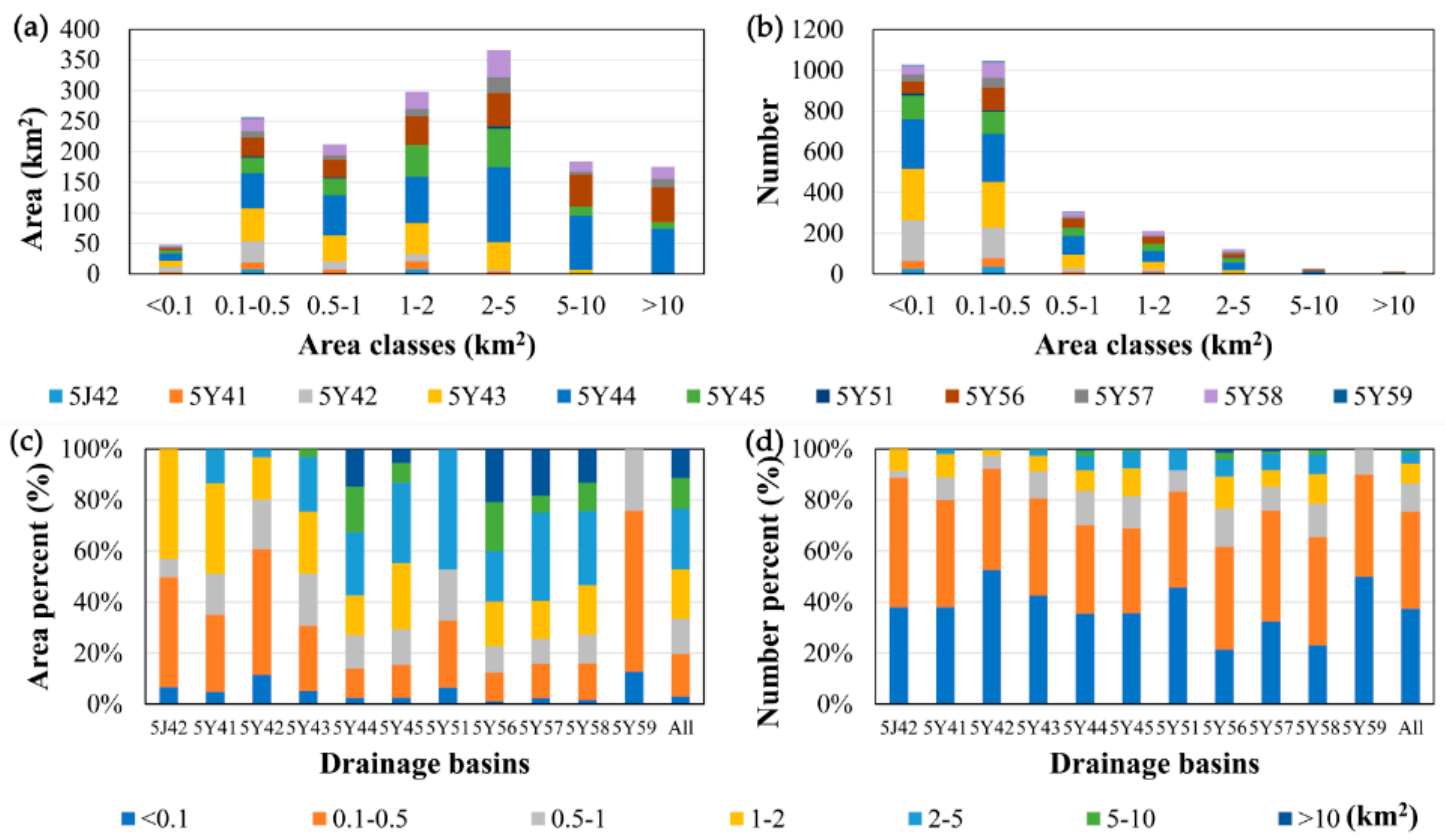

Figure 2. Total glaciers areas (a) and numbers (b) of the 2015 inventory and their respective proportions $(\mathbf{c}, \mathbf{d})$ within different area classes and different drainage basins.
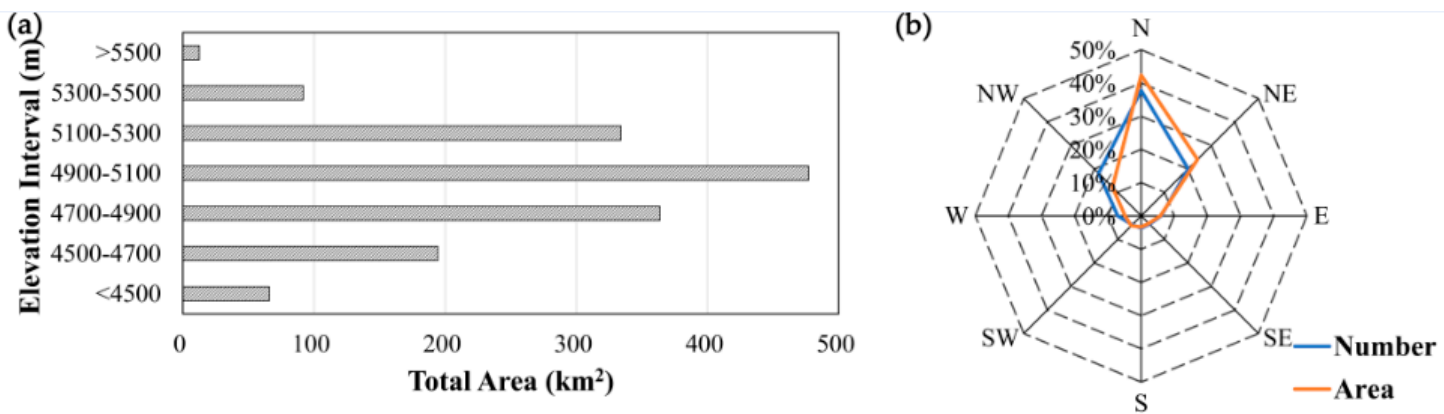

Figure 3. Glacier distribution by altitude and aspect. (a) Hypsography of glaciers area in the Qilian Mountains; (b) proportion of glacier number and area by mean aspect ( $45^{\circ}$ sectors).

Among all eight azimuth angles, the largest proportion of glacier aspects was north, which was approximately $40 \%$, in terms of both glacier numbers and areas. Glaciers with NE aspect roughly equaled to those with NW aspect in number, but were larger in glacier area, hence the NE facing glaciers were generally larger. There were few glaciers in the remaining five directions, accounting for $24.1 \%$ of number and $21.4 \%$ of area in total. The Qilian Mountains have one of the greatest north-south local glaciation asymmetries in the world. Figure $3 \mathrm{~b}$ shows a strong northward tendency in both area and number of glaciers, with slightly more in the northeast than northwest: in strong agreement with Evans's results [32], especially for the number of glaciers.

\subsection{The Characteristics of Glacier Changes}

\subsubsection{The Overall Glacier Area Variations}

From the 1960s to 2015, the area of glaciers in the Qilian Mountains shrank by $20.5 \% \pm 6.0 \%$ $\left(396.89 \pm 116.90 \mathrm{~km}^{2}\right)$ based on the FCGI and our data. Figure 4 shows changes in glacier number and combined area according to area size class. From the perspective of area change, almost all size classes 
of glaciers experienced a decreasing trend, except for $<0.1 \mathrm{~km}^{2}$ and $5-10 \mathrm{~km}^{2}$ over the past decades. The number of glaciers with an area of $<0.1 \mathrm{~km}^{2}$ increased from 589 to 1027 with the total area from $39.72 \mathrm{~km}^{2}$ to $47.23 \mathrm{~km}^{2}$, while that in the area range of $0.1-0.5 \mathrm{~km}^{2}$ had diminished from 1387 to 1044 , and the area correspondingly decreased from 354.60 to $256.32 \mathrm{~km}^{2}$. One possible explanation for the opposite change trends between two adjacent scale classes could be those relatively larger glaciers $\left(0.1-0.5 \mathrm{~km}^{2}\right)$ might have disintegrated or get shrunk as a result of melting, which would contribute to the rise in the smaller glaciers $\left(<0.1 \mathrm{~km}^{2}\right)$. The above analysis demonstrates that the number of glaciers in the Qilian Mountains was dominated by smaller glaciers with an area of less than $1 \mathrm{~km}^{2}(\sim 85 \%)$, while the area was dominated by glaciers in the $>1 \mathrm{~km}^{2}$ range $(\sim 65 \%)$.

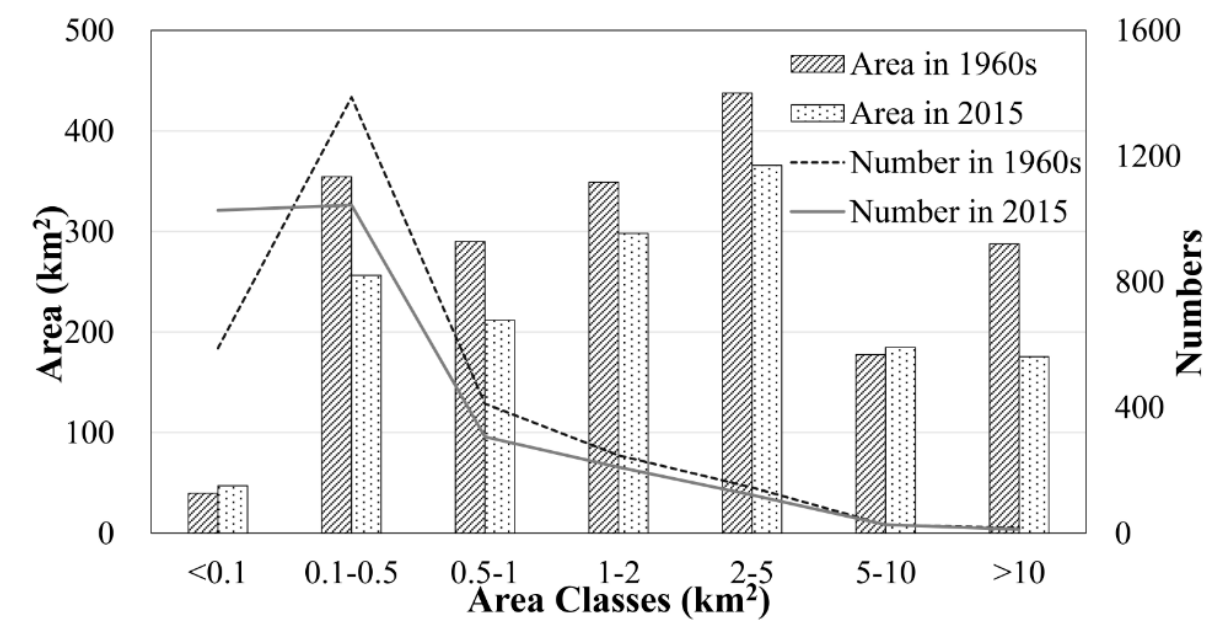

Figure 4. Size and count distributions of glacier in different area classes from three inventories.

Glacier changes in the Qilian Mountains varied by size, small glaciers had higher area change rates than large glaciers from the 1960s to 2015. Based on the relative changes in the area of each glacier (Figure 5), the glaciers in the Qilian mountains with an area of $<5.0 \mathrm{~km}^{2}$ had a larger range of change, while almost all $>5.0 \mathrm{~km}^{2}$ glaciers decreased by less than $20 \%$. The glaciers in the $<1 \mathrm{~km}^{2}$ range decreased by $63.6 \%$ of the total area loss, and most glaciers whose area shrinkage percentage was more than $50 \%$ were located in the range of $<1 \mathrm{~km}^{2}$, accounting for $39.5 \%$ of the total number of glaciers. These analyses revealed that $<1 \mathrm{~km}^{2}$ glaciers dominated both absolute and relative area changes.

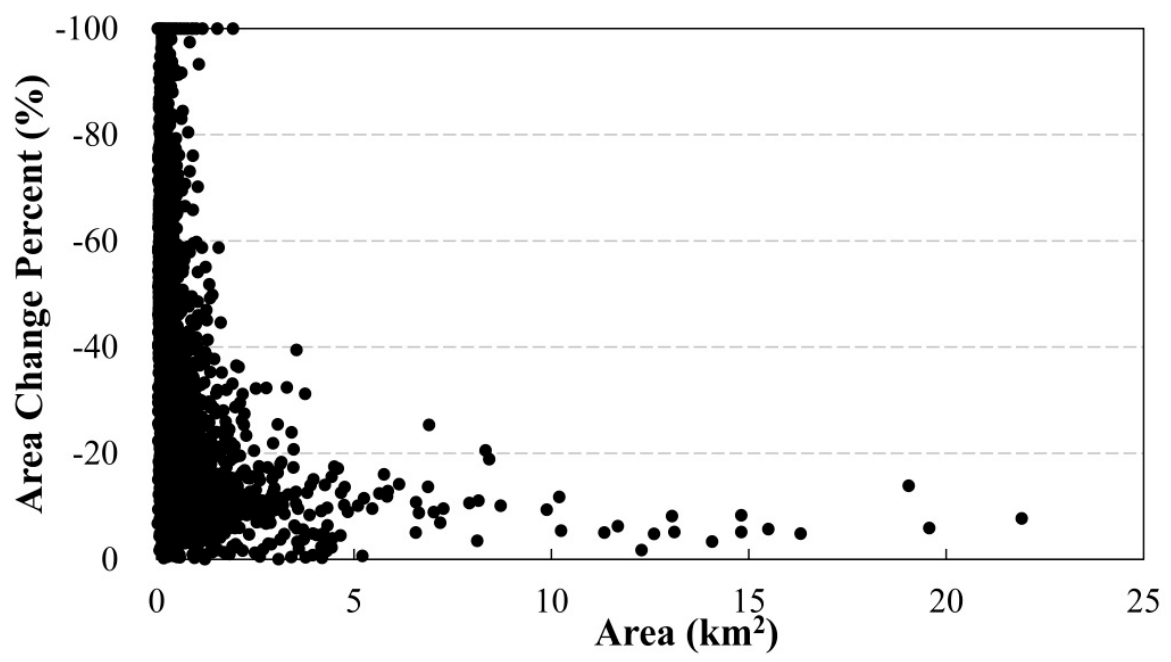

Figure 5. The area change percentage in glaciers in the Qilian Mountains from the 1960s to 2015.

The relationship of glacier area in the FCGI and the area change percent with longitude is shown in Figure 6. Overall, the glacier area in the eastern part was generally smaller than that in the western 
region, whereas their area change percentages were just the opposite. However, there was no definite pattern of changes in glacier area from west to east with longitude. This can be explained by lower elevation in the eastern Qilian Mountains.

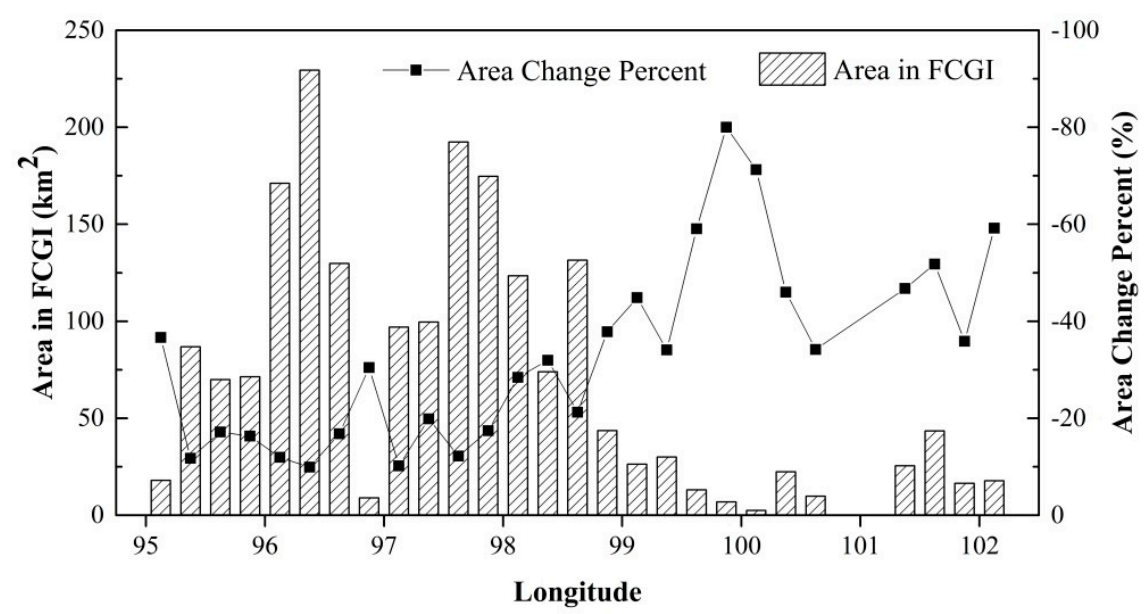

Figure 6. Glacier area proportion in FCGI and area changes with longitude from 1960s to 2015.

Figure 7 displays the results from our hypsometric analysis from the SCGI and our inventory. The Qilian Mountains had a unimodal distribution, with ice coverage above $5500 \mathrm{~m}$ remaining almost unchanged while the highest absolute ice loss occurred between 4700 and $4900 \mathrm{~m}$, accounting for $24.5 \%$ of the total area loss. In addition, the area recession of glaciers below $5100 \mathrm{~m}$ occupied $87.5 \%$ of general area change. There is a clear result that area losses increase as elevation decreases, meaning that equilibrium-line altitude (ELA) in balance with glacier geometry has risen. This is consistent with the study by Wang et al [33]. The ELA of the Qiyi Glacier in the mountains has generally increased by about $230 \mathrm{~m}$ from 1958 to 2008. Different recession rates were highlighted when glaciers classified into seven elevation intervals, as the percentage of glacier area change decreased with increasing elevation, with the greatest shrinkage percent of $14.9 \%$ for those lying $<4500 \mathrm{~m}$. The reason of which might be that glaciers at lower elevation without sufficient accumulation may have a faster response to climate change. Hence, the glaciers below $5100 \mathrm{~m}$ were overwhelmingly predominant in both absolute and relative area changes.

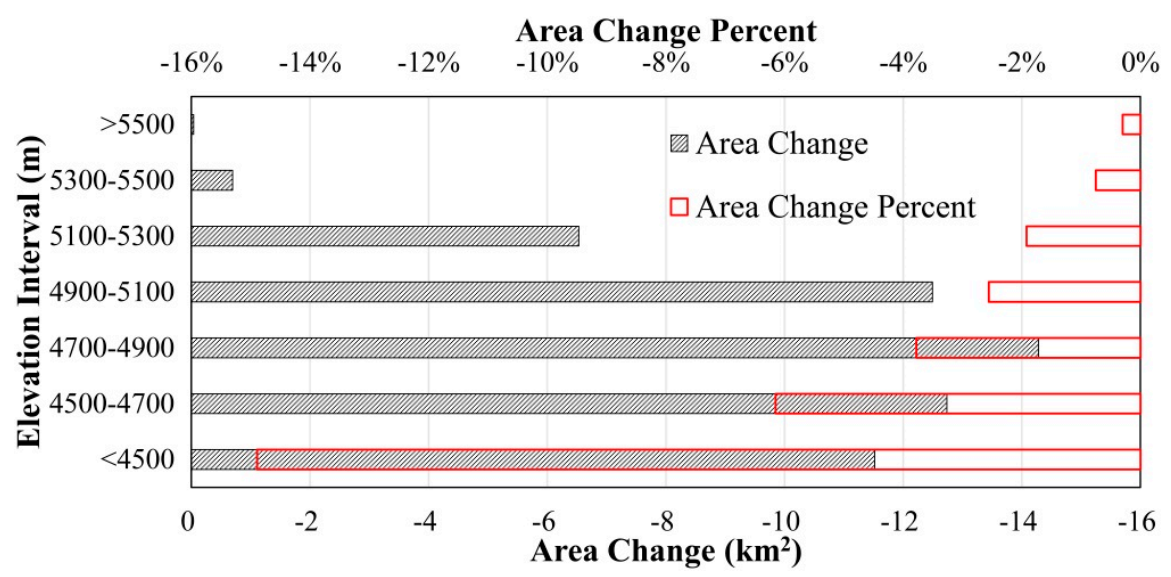

Figure 7. Area changes in glacier hypsometry based on the SCGI and our inventory. All hypsometry was calculated using SRTM (Shuttle Radar Topography Mission). 


\subsubsection{Comparisons of Glacier Area Variations between Different Inventories}

Statistical analysis indicates that glacier recession of both glacier area and area change rate have accelerated in all orientations over the past five years. The highest absolute area changes were observed on glaciers oriented northward $\left(165.92 \mathrm{~km}^{2}\right)$, followed by those with northeast $\left(91.93 \mathrm{~km}^{2}\right)$ and northwest $\left(62.28 \mathrm{~km}^{2}\right)$ orientations (Figure $8 \mathrm{~b}$ ), and there were similar area changes of glaciers oriented south, southeast and southwest from the 1960s to 2015. It should be noted that the absolute glacier area changes were consistent with the scale of total glaciers by orientations. From the perspective of area change percentage, the largest shrinkage of glaciers oriented southeast $(8.7 \% / 10 \mathrm{a})$, while glaciers facing northwest showed the least decrease (6.0\%/10a) from 2010 to 2015 . The reason may be that the smaller glaciers generally have NW-N-NE orientations.

(a)

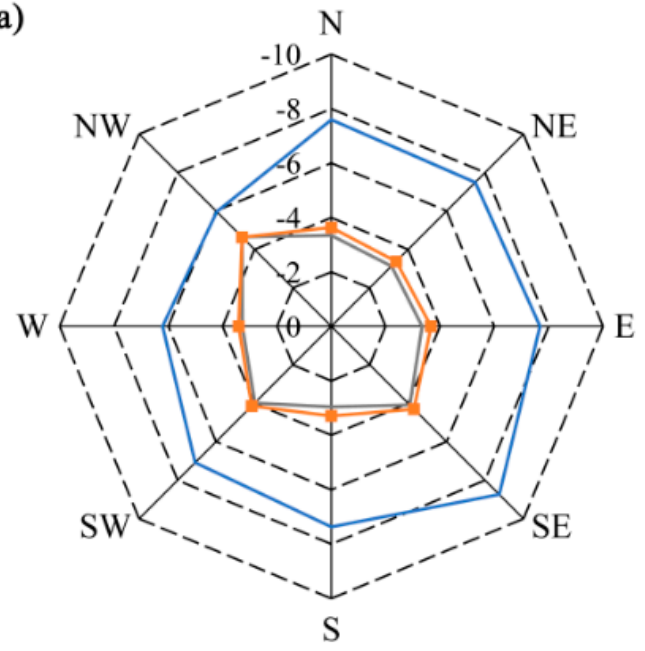

-FCGI-SCGI (b)

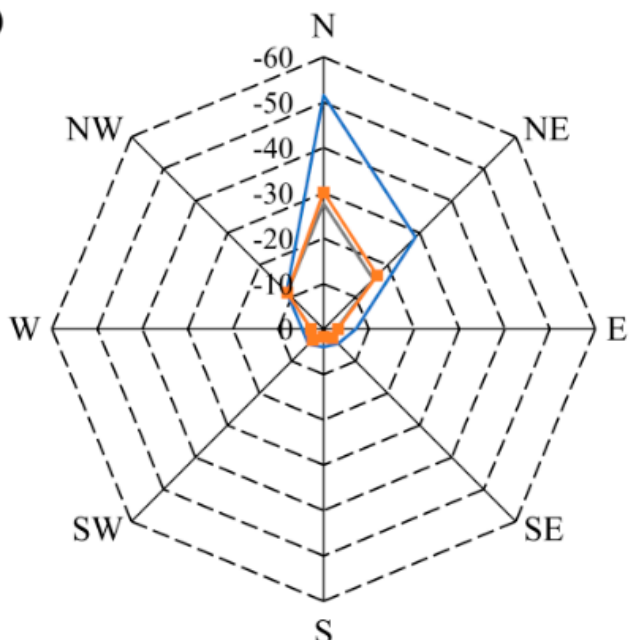

- -FCGI-Our Inventory

Figure 8. Orientation characteristics of glacier area changes in the Qilian Mountains: (a) glacier area decrease $(\% / 10 \mathrm{a})$, and $(\mathbf{b})$ area changes $\left(\mathrm{km}^{2} / 10 \mathrm{a}\right)$.

The spatial pattern of glacier shrinkage across the Qilian Mountains is illustrated in Figure 9. The area changes of glaciers at drainage scale had significant differences in the period from the 1960s to 2015, although they all experienced an accelerated shrink in both absolute and relative area change rates in recent years. Among all the drainage, the Shule River basin (5Y44) suffered from the most rapid change in glacier area with losses of $15.94 \mathrm{~km}^{2} / 10 \mathrm{a}$ and $25.04 \mathrm{~km}^{2} / 10 \mathrm{a}$ in the period of the 1960s to 2010 and 2010-2015, respectively. Next rapid decrease losses were found in the Beida River basin (5Y43) and Heihe River basin (5Y42). The Bayan Gol River basin (5Y59) had the lowest absolute losses of glacier area $\left(0.42 \mathrm{~km}^{2} / 10 \mathrm{a}\right)$, possibly due to its smallest glacier area among all the basins.

The relative change rate of glacier area showed an accelerated trend from west to east, while the area changes of the western region were much larger than eastern Qilian Mountains. From 1960s to 2015 , the fastest rate in the relative decrease (9.79\%/10a) occurred in the Datong River basin (5J42), followed by the Shiyang River basin (5Y41) and Heihe River basin (5Y42) with the relative rates of $8.27 \% / 10 \mathrm{a}$ and $8.20 \% / 10 \mathrm{a}$, respectively. By comparison, the relative decrease rates of five basins in the west of Har Lake were lower, with values below 2.85\%/10a. It was worth noting that the glaciers in the Shiyang River basin have changed fastest $(-2.30 \% / a)$ in the past five years. The spatial pattern of shrinkage rates in the Qilian Mountains is broadly consistent with patterns of area changes in the Tibetan Plateau and smaller samples reported earlier by Yao and others [6], and Liu and others [34]. 


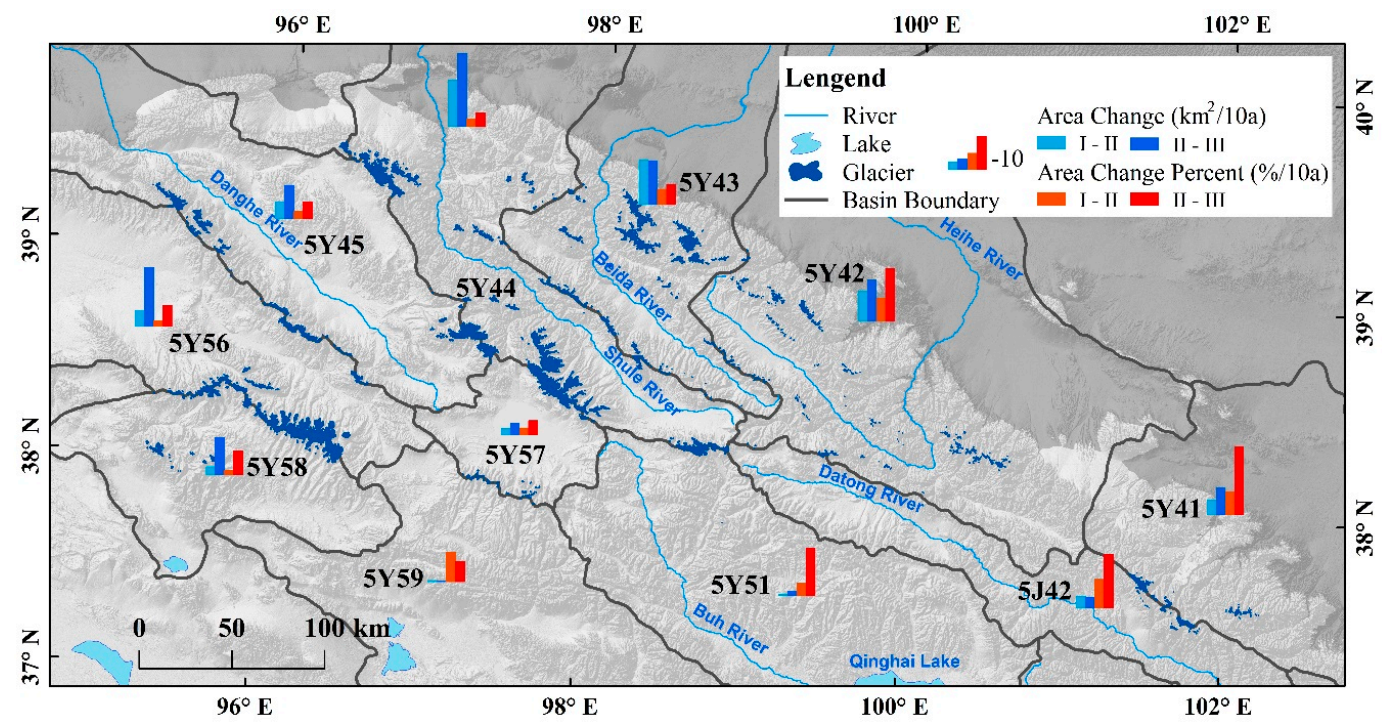

Figure 9. Area changes of glaciers at drainage scale in the Qilian Mountains from three inventories.

\subsubsection{The Disappearance of Glaciers}

Comparisons of the three inventories show that 109 glaciers with an area of $8.94 \mathrm{~km}^{2}$ disappeared over 1960s to 2015, while only 7 glaciers $\left(0.17 \mathrm{~km}^{2}\right)$ disappeared from 2010 to 2015 . Due to the limitation of topographic map scale and imagery resolution, glaciers with an area of less than $0.01 \mathrm{~km}^{2}$ were not considered for the disappearance situation. In addition, all disappeared glaciers have been verified in Google Earth. The statistical analysis demonstrated that disappeared glaciers were dominated by $<0.1 \mathrm{~km}^{2}$ glaciers $(52.0 \%$ of total area) and mostly in the elevation of $<4900 \mathrm{~m}(86.0 \%)$, while glaciers facing northeast $(28.3 \%)$, north $(24.4 \%)$ and northwest $(23.3 \%)$ tend to disappeared. This is consistent with relevant attributes of disappeared glaciers from 2010 to 2015 listed in Table 3. Figure 10 shows that the disappearance of glaciers was mainly found in the eastern part of the Qilian Mountains, with lower elevation, and the most serious disappearance occurred in the Heihe River basin (5Y42) and Datong River basin (5J42), with an area of $2.56 \mathrm{~km}^{2}$ and $1.71 \mathrm{~km}^{2}$, respectively.

Table 3. Some attributes of disappeared glaciers from 2010 to 2015.

\begin{tabular}{|c|c|c|c|c|c|c|c|}
\hline FCGI_ID & SCGI_ID & $\begin{array}{l}\text { Longitude } \\
\left({ }^{\circ}\right)\end{array}$ & $\begin{array}{l}\text { Latitude } \\
\left({ }^{\circ}\right)\end{array}$ & $\begin{array}{c}\text { Area FCGI } \\
\left(\mathrm{km}^{2}\right)\end{array}$ & $\begin{array}{c}\text { Area SCGI } \\
\left(\mathrm{km}^{2}\right)\end{array}$ & $\begin{array}{c}\text { Mean Elevation } \\
\text { (m) }\end{array}$ & $\begin{array}{c}\text { Aspect } \\
\left({ }^{\circ}\right)\end{array}$ \\
\hline 5Y417G0004 & G101456E37746N & 101.46 & 37.75 & 0.2 & 0.049 & 4319.10 & 23.40 \\
\hline 5Y427H0005 & G099131E38980N & 99.13 & 38.98 & 0.07 & 0.026 & 4896.70 & 144.60 \\
\hline 5Y429B0006 & G099079E38955N & 99.08 & 38.96 & 0.09 & 0.010 & 4629.70 & 32.70 \\
\hline 5Y435G0001 & G098587E38539N & 98.59 & 38.54 & 0.05 & 0.010 & 4684.30 & 12.80 \\
\hline 5Y435K0005 & G098432E38595N & 98.43 & 38.60 & 0.09 & 0.015 & 4686.00 & 15.20 \\
\hline 5Y571C0003 & G097356E38597N & 97.36 & 38.60 & 0.05 & 0.023 & 4972.80 & 44.30 \\
\hline 5Y581H0004 & G095607E37998N & 95.61 & 38.00 & 0.08 & 0.032 & 5126.30 & 24.50 \\
\hline
\end{tabular}




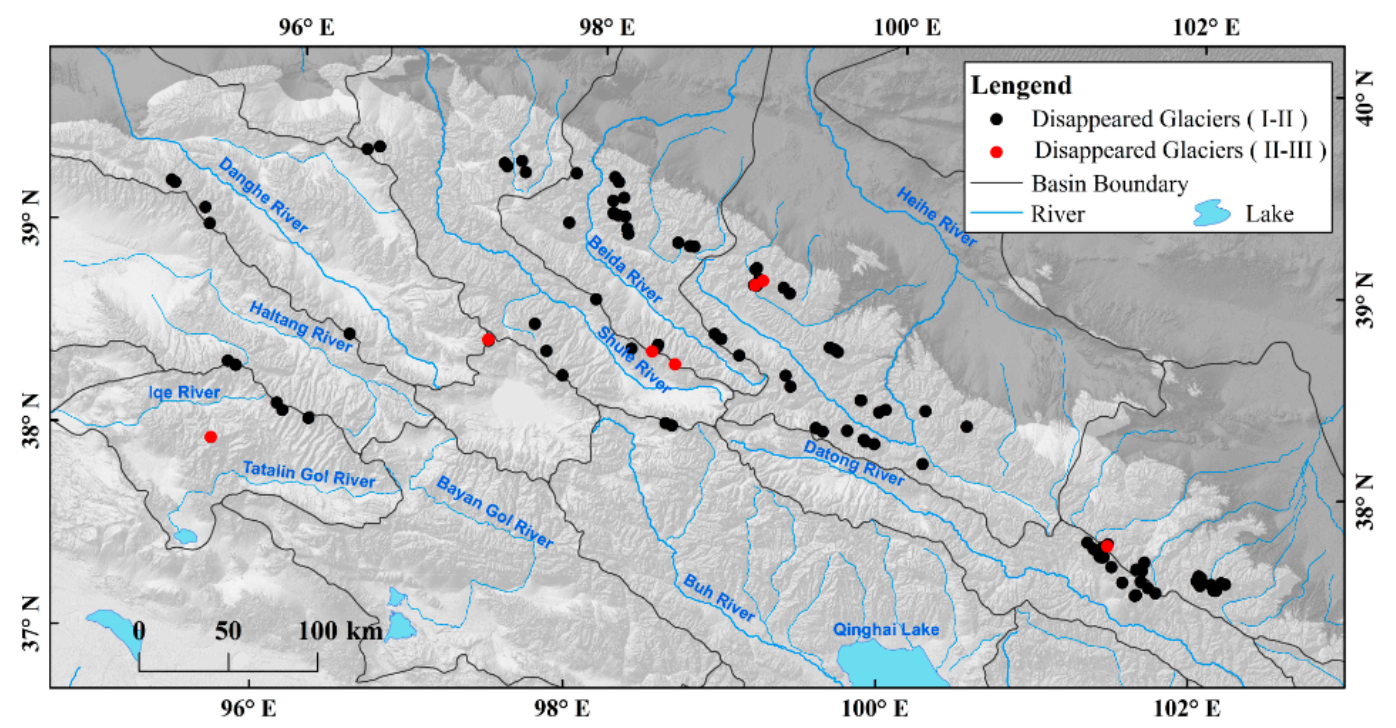

Figure 10. The location of disappeared glaciers from the 1960s to 2015.

\subsubsection{The Volume Changes of Glaciers}

We estimated the volume of glaciers using volume-area (V-A) scaling method based on three sets of empirical parameters (Table 4). In the present study, the V-A scaling was described as [35]:

$$
\mathrm{V}=\mathrm{cA}^{\gamma}
$$

where $\mathrm{V}$ and $\mathrm{A}$ are volume and area of a single glacier, while $\mathrm{c}$ and $\gamma$ are scaling parameters.

Table 4. Glacier volume changes based on three series of empirical parameters.

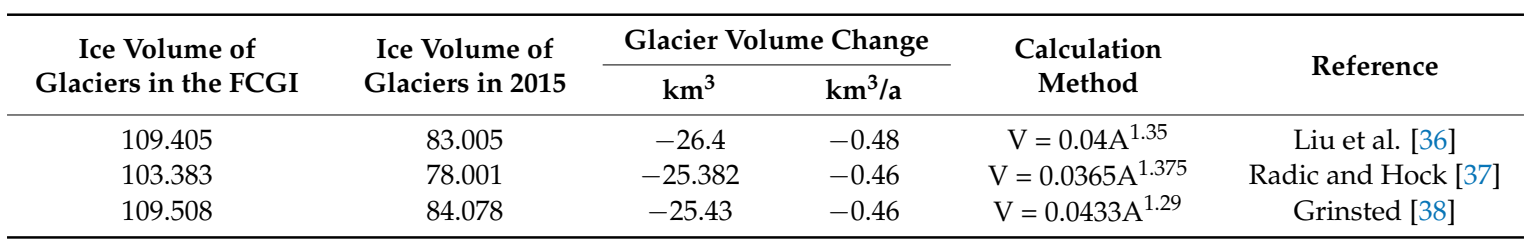

From 1960s to 2015, the average volume decrease of glaciers using different constants was $25.74 \mathrm{~km}^{3}$ in the Qilian Mountains, and the change rate of glacier ice volume loss was $-0.47 \mathrm{~km}^{3} / \mathrm{a}$ in the mountains.

In addition to the data above, we also employed previously published results from the literature (Table 5) to obtain temporally comprehensive information for the glacier mass balance or surface elevation changes. Some data of elevation changes were transformed from the mass balance results taking $850 \mathrm{~kg} \cdot \mathrm{m}^{-3}$ as the glacier density [39]. The surface elevation changes of the eastern mountain were obviously larger while the changes in glacier volume were precisely opposite, and this was due to the differences in total glacier area scale. Additionally, the glacier volume changes in the Qilian Mountains based on empirical formula showed a good consistency with that of in situ measurements.

Table 5. Glacier volume changes results used in this study.

\begin{tabular}{cccccc}
\hline Segment & Location & Period & dh/dt (m/a) & $\begin{array}{c}\text { Volume Changes } \\
\mathbf{( k m}^{\mathbf{3} / \mathbf{a})}\end{array}$ & Reference \\
\hline West region & Laohugou Glacier No.12 & $1957-2007$ & $-0.37 \pm 0.11$ & -0.26 & $\begin{array}{c}\text { Zhang et al. [40] } \\
\text { Yao et al. [6] } \\
\text { Central region }\end{array}$ \\
East region & Qiyi Glacier & $1975-2010$ & -0.212 & -0.18 & Cao [41] \\
\hline
\end{tabular}


Figure 11 shows a high consistency in the spatial pattern in the proportion of area and of volume changes between different basins. The glacier volume changes of all basins had an increased rate in recent years, and were more pronounced in the eastern Qilian Mountains than in other regions. In addition, the Datong River basin (5J42) experienced the fastest decrease (10.32\%/10a).

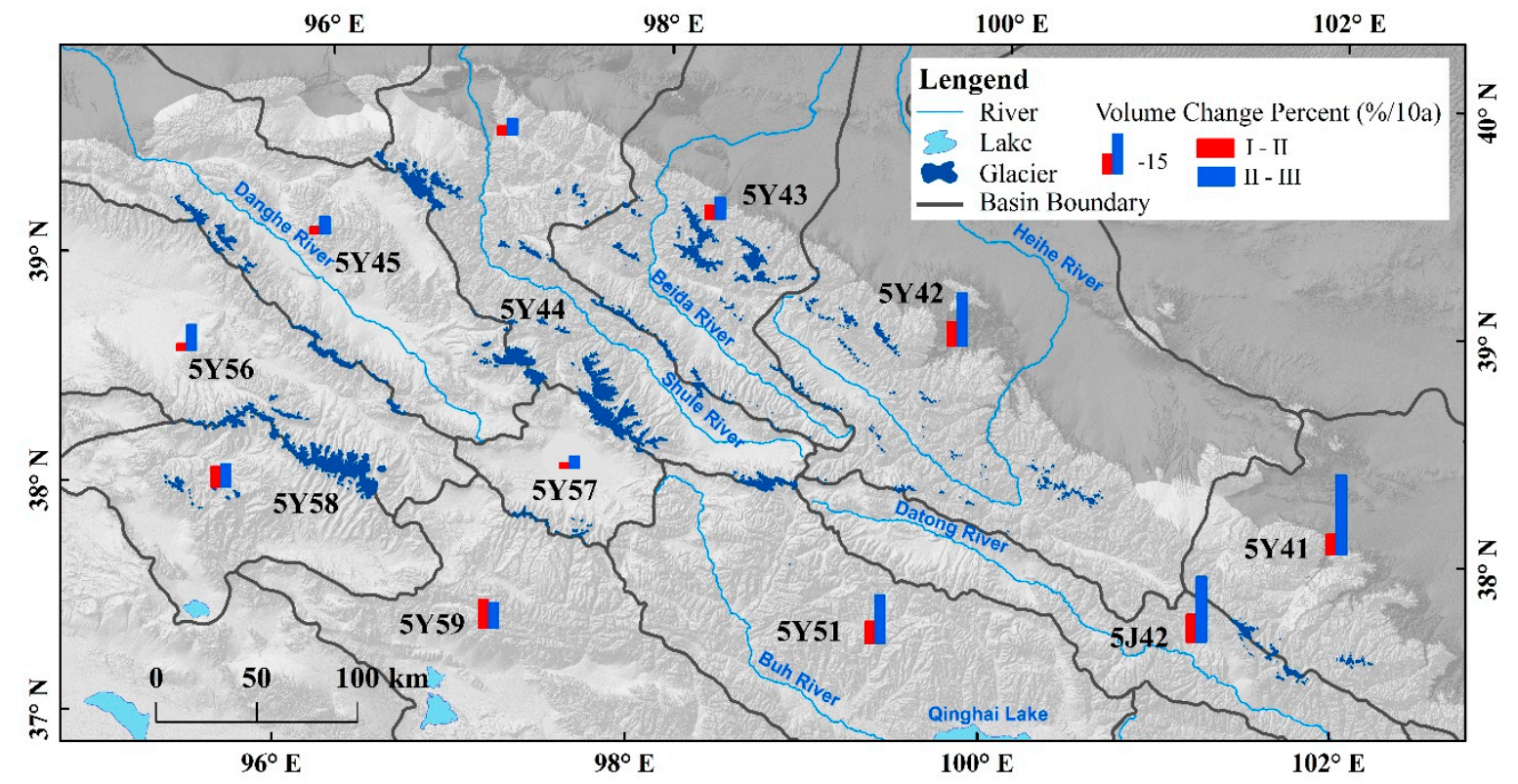

Figure 11. Volume change percent of glaciers in different basins from three inventories.

\subsection{Climatic Considerations}

Water (precipitation), heat (air temperature), and their combination are the main climatic factors affecting glacier development, and thus their interannual changes will influence the nature, development and evolution of glaciers [42]. Generally, the glacier mass balance is inversely related to temperature and positively correlated with precipitation [43]. Studies of mass balance modeling have shown that a $25 \%$ increase in annual precipitation is typically needed to compensate for the glacier melting caused by a $1 \mathrm{~K}$ warming [44]. In addition, the response of glacial changes to climate variations are not always immediate, and the time lag is generally several decades on average [28].

In this study, we discussed glacier changes due to regional climate using the monthly air temperature and precipitation data from the CRU and meteorological stations. Over the past five decades, the mean summer temperature in the Qilian Mountains has significantly increased by an average rate of $0.36^{\circ} \mathrm{C} / 10 \mathrm{a}$, while annual total precipitation also shows an upward trend in fluctuation by $9.61 \mathrm{~mm} / 10 \mathrm{a}$ (Figure 12). Both temperature and precipitation have regionally varied, and the spatial area change distributions of these two factors are often similar (Figure 13). For summer temperature changes, the rise rate decreases gradually from northwest to southeast, while the northern region has a faster rate of precipitation change in the Qilian Mountains.

Glacier distribution and shrinkage over the past decades had significant regional differences. Overall, considering the increasing trend of temperature and precipitation with different extent in the Qilian Mountains, these reductions are probably because the increased precipitation may not be sufficient to compensate for the melting effect of increasing temperature. The increasing temperature rate after 2000 may be the main reason for the accelerating retreat of glaciers during 2010-2015. Climatic differences in altitude involve important issues relating to warming [6]. There are larger temperature increases at higher elevation over the Tibetan Plateau [45]; however, such an increase tendency disappears above $5000 \mathrm{~m}$ [46]. Our study also shows few glacier changes in regions above $5500 \mathrm{~m}$, corresponding well with these results. In addition to these climatic factors, the distribution of the elevation of glacier terminus was also one of the key factors in influencing the glacial area 
shrinkage, as the average minimum elevation increased from east (4413.41 $\mathrm{m})$ to the west $(4826.53 \mathrm{~m})$. Therefore, the difference of glacier shrinkage rate in the eastern and western regions is likely to be related to the difference of altitude.
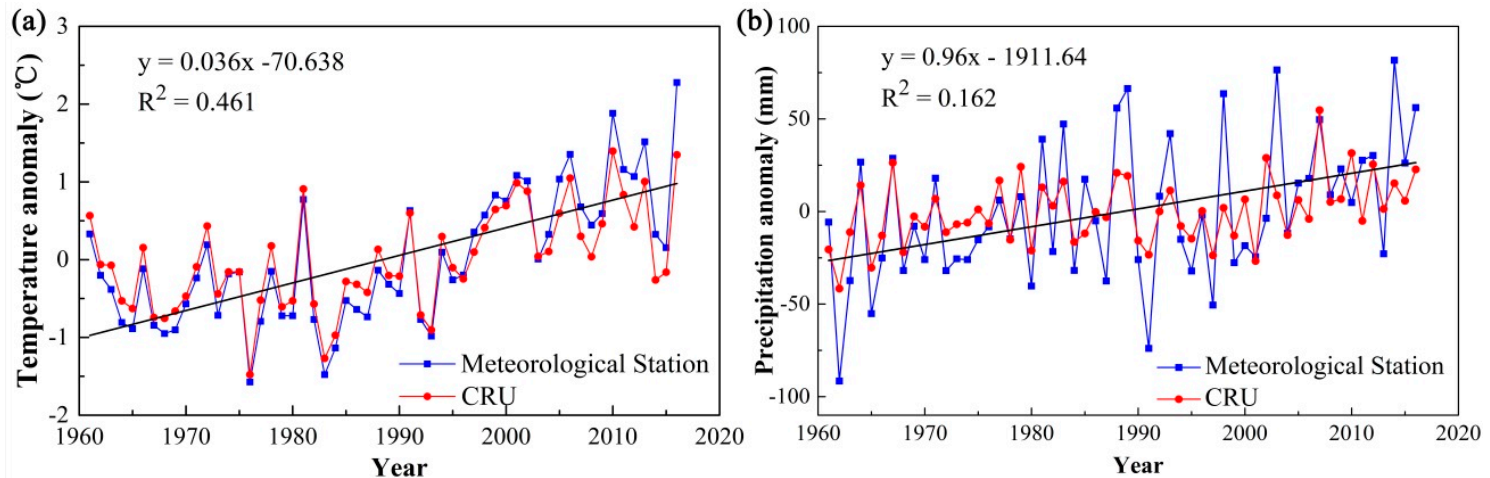

Figure 12. Anomalies analysis of mean summer temperature (a) and annual total precipitation (b) in the Qilian Mountains.
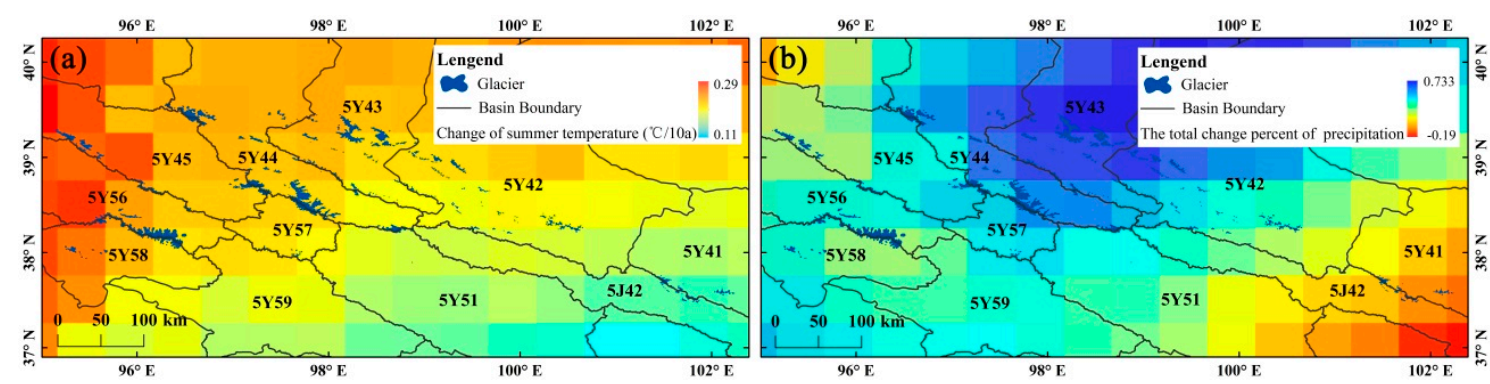

Figure 13. Changes in summer temperature (a) and total change percent in annual precipitation (b) from 1960 to 2015.

Furthermore, others factors are also important for glacier status, including size, type, condensation levels, sublimation, topography of glaciers or their combination effect [6], which prevent us from undertaking a quantitative analysis of the relative importance of specific climate factors on glacier changes.

\section{Conclusions}

There were 2748 glaciers covering $1539.30 \pm 49.50 \mathrm{~km}^{2}$ with an ice volume of $81.69 \pm 7.40 \mathrm{~km}^{3}$ in 2015 , and glaciers in the range of $2-5 \mathrm{~km}^{2}$ covered the largest area $(23.8 \%)$. Glaciers here have experienced continuous and accelerated retreat during this period. The ice-covered area decreased by $396.89 \mathrm{~km}^{2}(20.5 \%)$ with a mean shrinkage rate of $0.47 \% \mathrm{a}^{-1}$, and the average volume decrease of glaciers was $25.74 \mathrm{~km}^{3}\left(0.47 \mathrm{~km}^{3} \mathrm{a}^{-1}\right) ; 109$ glaciers $\left(8.94 \mathrm{~km}^{2}\right.$ in area) disappeared, with the most dramatic glacier shrinkage in the Shule River basin (5J42) (change rates of $0.98 \% \mathrm{a}^{-1}$ ). In addition, there was a spatial gradient across the mountains of glacier shrinkage rate, decreasing from the east to west.

The highest absolute ice loss was observed between 4700 and $4900 \mathrm{~m}$ (24.50\%), and the percentage of glacier area change gradually decreased with the increasing elevation. The absolute area shrinkage of glaciers with $\mathrm{N}$ and NE aspects exceeded that of others. The long-term glacier wastage is mainly attributed to the significant increase in air temperature during the wet season, although precipitation, glacier size, and local topographic parameters may have also influenced the nature of glacier retreat. With the given temperature increase, the ongoing trend of accelerated glacier recession is likely to continue. The inventory presented here will allow future research to focus on the assessment of the total glacier volume and hydrologic modelling. 
Author Contributions: Conceptualization, J.H. and N.W.; methodology, J.H. and A.C.; software, J.H.; validation, X.Y.; formal analysis, J.H. and A.C.; investigation, X.Y.; resources, A.C.; data curation, J.H.; writing-original draft preparation, J.H.; writing-review and editing, N.W., X.Y. and T.H.; visualization, J.H. and T.H.; funding acquisition, N.W. and A.C.

Funding: This research was funded by the Strategic Priority Research Program of the Chinese Academy of Sciences (grant numbers XDA20060201, XDA19070302, and XDA20060700), and the National Natural Science Foundation of China (grant numbers 41801035, 41601080, and 41571076).

Acknowledgments: We gratefully acknowledge NASA for the provision of remote-sensing data, as well as the Climatic Research Unit and the China Meteorological Administration for climate data. We thank the editors and anonymous reviewers for their constructive comments on this manuscript.

Conflicts of Interest: The authors declare no conflict of interest.

\section{References}

1. Oerlemans, J. Quantifying global warming from the retreat of glaciers. Science 1994, 264, 243-245. [CrossRef] [PubMed]

2. Stocker, T.F.; Qin, D.; Plattner, G.K.; Tignor, M.; Allen, S.K.; Boschung, J.; Nauels, A.; Xia, Y.; Bex, V. The physical science basis. Contribution of Working Group I to the Fifth Assessment Report of the Intergovernmental Panel on Climate Change. Comput. Geom. 2013, 18, 95-123.

3. Kargel, J.S. Global Land Ice Measurements from Space; Springer: Berlin/Heidelberg, Germany, 2014; pp. $205-228$.

4. Rivera, A.; Casassa, G.; Bamber, J.; Kääb, A. Ice elevation changes of Glaciar Chico, southern Patagonia, using ASTER DEMs, aerial photographs and GPS data. J. Glaciol. 2008, 51, 105-112. [CrossRef]

5. Zemp, M.; Frey, H.; Gärtnerroer, I.; Nussbaumer, S.U.; Hoelzle, M.; Paul, F.; Haeberli, W.; Denzinger, F.; Ahlstrøm, A.P.; Anderson, B. Historically unprecedented global glacier decline in the early 21st century. J. Glaciol. 2015, 61, 745-762. [CrossRef]

6. Yao, T.; Thompson, L.; Yang, W.; Yu, W.; Yang, G.; Guo, X.; Yang, X.; Duan, K.; Zhao, H.; Xu, B. Different glacier status with atmospheric circulations in Tibetan Plateau and surroundings. Nat. Clim. Chang. 2012, 2, 663-667. [CrossRef]

7. Zhang, J.; He, X.; Shangguan, D.; Zhong, F.; Liu, S. Impact of Intensive Glacier Ablation on Arid Regions of Northwest China and Its Countermeasure. J. Glaciol. Geocryol. 2012, 34, 848-854.

8. Tian, H.; Yang, T.; Liu, Q. Climate change and glacier area shrinkage in the Qilian mountains, China, from 1956 to 2010. Ann. Glaciol. 2017, 55, 187-197. [CrossRef]

9. Sun, M.; Liu, S.; Yao, X.; Guo, W.; Xu, J. Glacier changes in the Qilian Mountains in the past half-century: Based on the revised First and Second Chinese Glacier Inventory. J. Geogr. Sci. 2018, 28, 206-220. [CrossRef]

10. Wang, Y.; Ren, J.; Qin, D.; Qin, X. Regional Glacier Volume Changes Derived from Satellite Data: A Case Study in the Qilian Mountains. J. Glaciol. Geocryol. 2013, 35, 583-592.

11. Jacob, T.; Wahr, J.; Pfeffer, W.T.; Swenson, S. Recent contributions of glaciers and ice caps to sea level rise. Nature 2012, 482, 514-518. [CrossRef]

12. Li, Z.; Qin, X.; Wang, J.; Liu, Y.; Jing, H. Glaciers distribution characteristics and change detection from 2004 to 2015 in the Lenglongling in the east of Qilian mountains. Sci. Surv. Mapp. 2018, 43, 45-51.

13. Wang, J.; Qin, X.; Li, Z.; Liu, Y.; Jing, H. Glaciers Change Detection from 2004 to 2015 in the Daxueshan, Qilian MTS. Remote Sens. Technol. Appl. 2017, 32, 490-498.

14. Paul, F.; Barry, R.G.; Cogley, J.G.; Frey, H.; Haeberli, W.; Ohmura, A.; Ommanney, C.S.L.; Raup, B.; Rivera, A.; Zemp, M. Recommendations for the compilation of glacier inventory data from digital sources. Ann. Glaciol. 2009, 50, 119-126. [CrossRef]

15. You, L.; Yang, J. Geomorphology in China; Science Press: Beijing, China, 2013.

16. Wang, Z.; Liu, C.; You, G. Glacier Inventory of China I Qilian Mountains; Lanzhou Institute of Glaciology and Cryopedology, CAS: Lanzhou, China, 1981.

17. Liu, S.; Yao, X.; Guo, W.; Xu, J.; Shangguan, D.; Wei, J.; Bao, W.; Wu, L. The contemporary glaciers in China based on the Second Chinese Glacier Inventory. Acta Geogr. Sin. 2015, 70, 3-16.

18. Guo, W.; Liu, S.; Xu, J.; Wu, L.; Shangguan, D.; Yao, X.; Wei, J.; Bao, W.; Yu, P.; Liu, Q. The second Chinese glacier inventory: Data, methods and results. J. Glaciol. 2015, 61, 357-372. [CrossRef] 
19. Nuimura, T.; Sakai, A.; Taniguchi, K.; Nagai, H.; Lamsal, D.; Tsutaki, S.; Kozawa, A.; Hoshina, Y.; Takenaka, S.; Omiya, S. The GAMDAM Glacier Inventory: A quality controlled inventory of Asian glaciers. Cryosphere Discuss. 2015, 8, 849-864. [CrossRef]

20. Racoviteanu, A.E.; Paul, F.; Raup, B.; Khalsa, S.J.S.; Armstrong, R. Challenges and recommendations in mapping of glacier parameters from space: Results of the 2008 Global Land Ice Measurements from Space (GLIMS) workshop, Boulder, Colorado, USA. Ann. Glaciol. 2009, 50, 53-69. [CrossRef]

21. Bolch, T.; Buchroithner, M.; Pieczonka, T.; Kunert, A. Planimetric and volumetric glacier changes in the Khumbu Himal, Nepal, since 1962 using Corona, Landsat TM and ASTER data. J. Glaciol. 2008, 54, 592-600. [CrossRef]

22. Graham, C.J. Glacier shrinkage across High Mountain Asia. Ann. Glaciol. 2016, 57, 41-49.

23. Zemp, M.; Armstrong, R.; Gärtner-Roer, I.; Haeberli, W.; Hoelzle, M.; Kääb, A.; Kargel, J.S.; Khalsa, S.J.S.; Leonard, G.J.; Paul, F. Introduction: Global Glacier Monitoring-A Long-Term Task Integrating in Situ Observations and Remote Sensing. In Global Land Ice Measurements from Space; Springer: Berlin/Heidelberg, Germany, 2014.

24. Raup, B.; Kääb, A.; Kargel, J.S.; Bishop, M.P.; Hamilton, G.; Lee, E.; Paul, F.; Rau, F.; Soltesz, D.; Khalsa, S.J.S. Remote sensing and GIS technology in the Global Land Ice Measurements from Space (GLIMS) Project. Comput. Geosci. 2007, 33, 104-125. [CrossRef]

25. Paul, F.; Andreassen, L.M. A new glacier inventory for the Svartisen region, Norway, from Landsat ETM+ data: Challenges and change assessment. J. Glaciol. 2009, 55, 607-618. [CrossRef]

26. Pfeffer, W.T.; Arendt, A.A.; Bliss, A.; Bolch, T.; Cogley, J.G.; Gardner, A.S.; Hagen, J.O.; Hock, R.; Kaser, G.; Kienholz, C. The Randolph Glacier Inventory: A globally complete inventory of glaciers. J. Glaciol. 2014, 60, 537-552. [CrossRef]

27. Granshaw, F.D.; Fountain, A.G. Glacier change (1958-1998) in the North Cascades National Park Complex, Washington, USA. J. Glaciol. 2006, 52, 251-256. [CrossRef]

28. Bolch, T.; Yao, T.; Kang, S.; Buchroithner, M.F. A glacier inventory for the western Nyainqentanglha Range and the Nam Co Basin, Tibet, and glacier changes 1976-2009. Cryosphere 2010, 4, 419-433. [CrossRef]

29. Hall, D.K.; Bayr, K.J.; Schöner, W.; Bindschadler, R.A.; Chien, J.Y.L. Consideration of the errors inherent in mapping historical glacier positions in Austria from the ground and space (1893-2001). Remote Sens. Environ. 2003, 86, 566-577. [CrossRef]

30. Bris, R.L.; Paul, F. An automatic method to create flow lines for determination of glacier length: A pilot study with Alaskan glaciers. Comput. Geosci. 2013, 52, 234-245. [CrossRef]

31. Hagg, W.; Mayer, C.; Lambrecht, A.; Kriegel, D.; Azizov, E. Glacier changes in the Big Naryn basin, Central Tian Shan. Glob. Planet. Chang. 2013, 110, 40-50. [CrossRef]

32. Evans, I.S. Local aspect asymmetry of mountain glaciation: A global survey of consistency of favoured directions for glacier numbers and altitudes. Geomorphology 2006, 73, 166-184. [CrossRef]

33. Wang, N.; He, J.; Pu, J.; Jiang, X.; Jing, Z. Variations in equilibrium line altitude of the Qiyi Glacier, Qilian Mountains, over the past 50 years. Chin. Sci. Bull. 2010, 55, 3810-3817. [CrossRef]

34. Liu, S.; Ding, Y.; Li, J.; Shangguan, D.; Zhang, Y. Glaciers in response to recent climate warming in western China. Quat. Sci. 2006, 26, 762-771.

35. Zhang, Z.; Xu, J.; Liu, S.; Guo, W.; Wei, J.; Feng, T. Glacier changes since the early 1960s, eastern Pamir, China. J. Mt. Sci. 2016, 13, 276-291. [CrossRef]

36. Liu, S.; Sun, W.; Shen, Y.; Gang, L. Glacier changes since the Little Ice Age maximum in the western Qilian Shan, Northwest China, and consequence of glacier runoff for water supply. J. Glaciol. 2017, 49, 117-124.

37. Radic, V.; Hock, R. Regional and global volumes of glaciers derived from statistical upscaling of glacier inventory data. J. Geophys. Res. 2010, 115, F01010. [CrossRef]

38. Grinsted, A. An estimate of global glacier volume. Cryosphere 2013, 7, 141-151. [CrossRef]

39. Huss, M. Density assumptions for converting geodetic glacier volume change to mass change. Cryosphere 2013, 7, 877-887. [CrossRef]

40. Zhang, Y.; Liu, S.; Shangguan, D.; Li, J.; Zhao, J. Thinning and Shrinkage of Laohugou No. 12 Glacier in the Western Qilian Mountains, China, from 1957 to 2007. J. Mt. Sci. 2012, 9, 343-350. [CrossRef]

41. Cao, B.; Pan, B.; Gao, H.; Jiang, S.; Wen, Y.; Shangguan, D. Glacier Variation in the Lenglongling Range of Eastern Qilian Mountains from 1972 to 2007. J. Glaciol. Geocryol. 2010, 32, 242-248.

42. Xie, Z.; Liu, C. Introduction to Glaciology; Shanghai Science Popular Press: Shanghai, China, 2010. 
43. Li, Z.; Han, T.; Jing, Z.; Yang, H.; Jiao, K. A Summary of 40-Year Observed Variation Facts of Climate and Glacier No.1 at Headwater of Ürümqi River, Tianshan, China. J. Glaciol. Geocryol. 2003, 25, 117-123.

44. Oerlemans, J. Extracting a climate signal from 169 glacier records. Science 2005, 308, 675-677. [CrossRef] [PubMed]

45. Liu, X.; Chen, B. Climatic warming in the Tibetan plateau during recent decades. Int. J. Climatol. 2015, 20, 1729-1742. [CrossRef]

46. Qin, J.; Yang, K.; Liang, S.; Guo, X. The altitudinal dependence of recent rapid warming over the Tibetan Plateau. Clim. Chang. 2009, 97, 321-327. [CrossRef]

(C) 2019 by the authors. Licensee MDPI, Basel, Switzerland. This article is an open access article distributed under the terms and conditions of the Creative Commons Attribution (CC BY) license (http:/ / creativecommons.org/licenses/by/4.0/). 